\title{
A GIS-based Assessment of the Vulnerability to Potential Pollution of the Alluvial Aquifer of Aousja-Ghar El Melh (North-East of Tunisia) Using the Parametric Method DRASTIC
}

\author{
Sarra Ouerghi
}

\begin{abstract}
The phreatic aquifer of Aousja-Ghar El Melh (governorate of Bizerta, northeast of Tunisia), has a great economic weight as it is tightly linked to irrigation and domestic consumption. The aquifer area is found mostly in agricultural zones where more and more chemical fertilizers are being used. Such chemical fertilizers, alongside industrial zones discharges appearing for the last 25 years, put at risk ground waters quality. The DRASTIC method has been applied to study the extent to which the aquifer has been affected by generic pollutants. This method hinges on GIS techniques. The result suggests a map with evidence for three degrees of vulnerability: low, moderate, and high. Evidence shows the predominance of moderate vulnerability in most of Aousja-Ghar El Melh aquifer, which occupies an area of $45 \%$. Low and high groundwater vulnerability occupy $28 \%$ and $27 \%$ of the total surface of the studied area, respectively.
\end{abstract}

Index Terms - Aousja-Ghar El Melh, GIS technique DRASTIC Model, Phreatic aquifer, Pollution, Vulnerability.

\section{INTRODUCTION}

The environmental concerns are often groundwater-related and concentrate generally on the effect of pollution and the quality degradation with regard to the human uses, the reserve domesticates in particular. Because of high growth population and industrialization, the important quantities of domestic and industrial effluents are the most important sources of groundwater pollution.

Groundwater quality is more important than quantity, given its being the sole drinking water source in most Tunisian urban areas. Recently, the quality of the drinking water in Tunisian cities has deteriorated because of population growth, lack of strategic growth plan, mixture of land use, absence of the appropriate sewers and poor control of wastewater disposal, and leftover water from human and industrial activities. The result is the pollution of shallow aquifers in and around Tunisian cities in general, and in Aousja-Ghar El Melh in particular.

Groundwater pollution is only an induced degradation of their natural quality. Contrary to surface water pollution, it is difficult to detect and control groundwater pollution- a pollution that can linger not only for years, but also for decades, or even for centuries [1]. Groundwater vulnerability is affected by the zone geologic arrangement, which largely

Submitted on January 27, 2021.

Published on February 15, 2021.

Sarra Ouerghi, Department of Geography and GIS, Faculty of Arts \& Humanities, King Abdulaziz University, Jeddah, Saudi Arabia; Laboratoire controls the water path (which is mainly in a rain form) infiltrated by the soil, until it reaches the aquifer and begins its subsurface flow [2]. In any zone, the groundwater, be it in aquifer or produced by wells, has the same contamination vulnerability by pollutants resulting from human activities.

Vulnerability is a concept which appeared in the 1960s. Yet, there does not seem to be a standard definition of the aquifer vulnerability. According to [3], aquifer vulnerability can be defined as a concept encapsulating the constitutive characteristics of aquifer systems as related to their sensibility to activities, be they human or natural.

The mapping of the vulnerability is identified as a technique to quantify the sensibility of a resource to its environment, and as a tool of practical display for decision making. The groundwater vulnerability is also classified as the trend and the probability for the pollutants reaching groundwater. In fact, the term groundwater vulnerability was used at first by [4].

With the increasing importance of groundwater resources, the efforts increase to prevent, reduce and eliminate the pollution of these waters. The DRASTIC model can be very efficient to identify the zones of aquifer which are vulnerable to contamination by using hydro-geologic variables which facilitate the transport of pollutant resulting from a superficial source towards groundwater [5].

This study mainly aims at estimating groundwater vulnerability in a shallow aquifer, with emphasis on pollution using the coupling between the GIS and the DRASTIC model in association with the hydro-geologic layers such as Net Recharge, Depth to water, Soil media, Aquifer media, Topography, Impact of the vadose zone, and Hydraulic Conductivity.

\section{STUDY AREA}

Located in the governorate of Bizerte, in the Northeast of Tunisia (Fig. 1), the Aousja-Ghar El Melh aquifer is situated at the foothills of Ennadhour and Kechabta mountains. This aquifer is located in a coastal plain (Utique Plain) essentially exploited in agriculture and where more and more industrial installations become established. The study area is bordered to the north by the Demnia, Ennadhour mountains and it is bounded in the west by the Kechabta mountain, in the south

3E «Eau-Energie-Environnement» (LRAD-10-02), Ecole Nationale d'Ingénieurs de Sfax, Tunisie.

(e-mail: sarahouerghi@gmail.com). 
by Menzel Ghoul mountain and in the east by the Ghar el Melh lagoon and the Mediterranean Sea (Fig. 1).

Agriculture and farming represent most of the practised activities by the population of the Aousja-Ghar El Melh region. These activities are based on groundwater resources circulating in shallow depths. This zone shows, a priori, a sensitive zone to the contamination.

The Aousja-Ghar El Melh acquifer has a Mediterranean climate with subhumide nuance because the annual rainful average is about $500 \mathrm{~mm}$ with a rainy winter and a hot and dry summer. Pluviometry is often concentrated in time, is irregular and is unequally distributed over the various seasons.

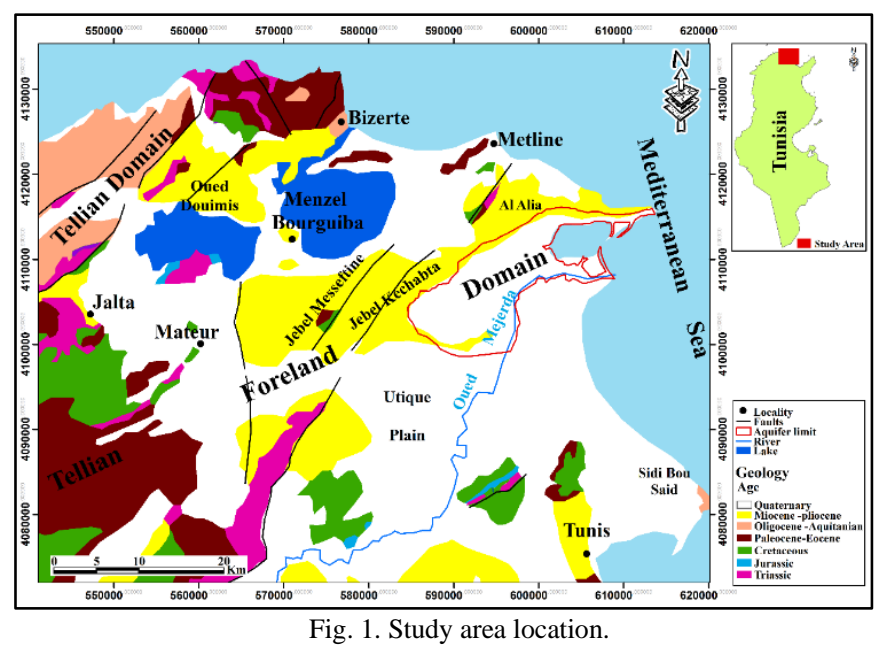

The annual number of rainy days exceeds, rarely, 100 days and the irregularity are particularly notable in spring. The great decline of rainful values is recorded between September and April. The distribution of the rainful and the temperatures influences the chemistry of waters by dilution during the rainy period, or concentration by the evaporation during dry period. The interannual average of rainful is about $450 \mathrm{~mm} /$ year. The annual evapotranspiration is about $1500 \mathrm{~mm} /$ year.

The Aousja-Ghar El Melh aquifer is a coastal aquifer located in the Plio-Quaternary, whose groundwater resources are essentially divided into two aquifer levels:

The phreatic aquifer is located in the quaternary detrital formations, consisting essentially of alluvial deposits, sandy clay and sands up to $50 \mathrm{~m}$ thick. In contrast, the underlying aquifer, captures the sand and sandstone of the pliocene on the outcrop or under the cover of the Quaternary, which reached a rating of $200 \mathrm{~m}$ at the Besbassia borehole.

The deep aquifer, essentially marine, is in the sandy pliocene. It is located mostly in the north-west and south-east edges of the Douimis, Messeftine, Kechabta and El Alia basins (Fig. 1). It is made up of two formations: (i) the argillaceous Om Elmelah Formation (Early Pliocene) at the base constituting the wall of the aquifer, and(ii) the sandy Kechabta Formation (Late Pliocene) at the top (Fig. 2D) [6], [7], [8]. Continental facies in the depocenters and basin margins are shown in The Quaternary succession. Marine strata are found along coastaline areas [9], [10].

\section{Methodology}

This study uses the DRASTIC method, which is a standard system for assessing potential groundwater pollution. The DRASTIC model is commonplace in a great number of countries, mainly because it allows for a consideration of the hydrogeological factors that influence and control groundwater flow [11] and uses the input data (the data requires this model for the application) which are readily available. They can also be made available by multiple government agencies. This model serves the purpose of protecting groundwater in the United States of America. This methodology is developed following cooperation between the National (American) Water Well Association and the American Environmental Protection Agency [12]. This model was designed to systematically assess potential groundwater pollution.

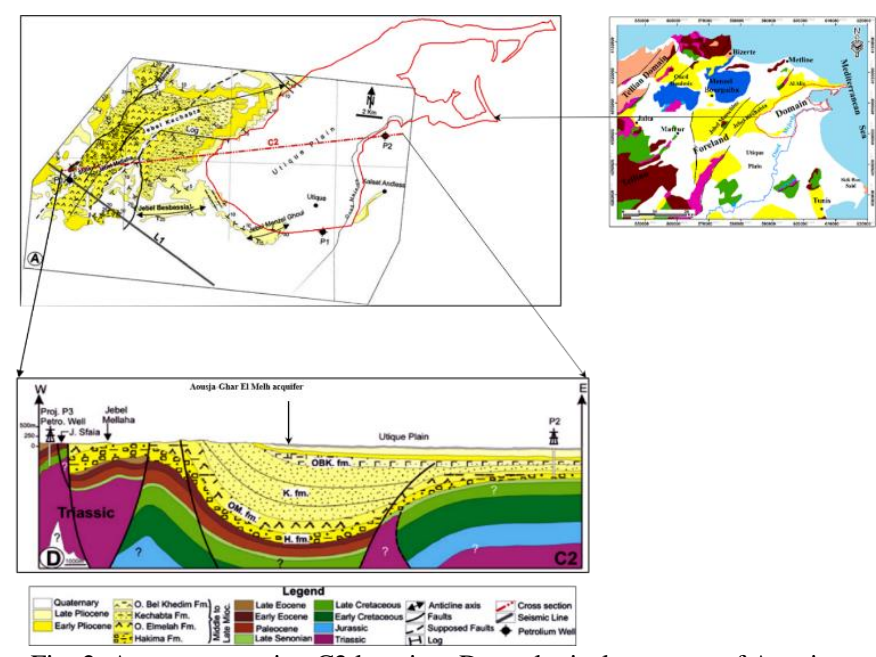

Fig. 2. A: a cross-section C2 location; D: geological structure of AousjaGhar El Melh aquifer [13]

The DRASTIC model hinges on seven parameters, corresponding to seven layers of information which are in turn used as input data for modelling (Fig. 3), which were obtained from various governmental agencies with different scales (Table I). The acronym DRASTIC stands for the seven basic parameters' initials [12]:

\section{Depth to water}

Refers to water surface depth in unconfined aquifer. The deeper the water table levels, the lesser the chance for contamination. Depth of water is indicative of depth as related to the confined aquifer top.

\section{Net Recharge}

Signifies the water amount per land area unit, penetrating the ground surface and reaching the water table. Recharge water transmits a contaminant vertically to the water table, and horizontally within an aquifer.

\section{Aquifer media}

It is the unconsolidated or consolidated medium which serves as an aquifer. Pollution potential increases with higher permeability and lower attenuation capacity. This is also linked to how large the grain size is, and the number of fractures and openings in an aquifer.

\section{Soil media}

Soil, as the first layer exposed to pollutants, is important and has a substantial effect on recharge. Potential of soil contamination depends on properties including texture, 
permeability, organic matter content and soil thickness. Soil texture is linked to sand, silt and clay particles. In coarse sandy soils, water moves quickly, and therefore is less able to absorb chemicals by its own organic matter. High permeability of soil increases the leakage of pollutants into the table. Organic matter content affects soil ability to retain and absorb pollutants. Soil thickness also influences pollution reduction. The higher the soil thickness, the greater the opportunity for pollution reduction processes to diminish pollutants in the soil. In general, it can be claimed that fine grained soils with low permeability and high clay content cause little potential for groundwater pollution.

\begin{tabular}{cccc}
\multicolumn{4}{c}{ TABLE I: THE DATA USED FOR THE DRASTIC MODELS } \\
\hline \hline Data & Data Sources & Format & Output \\
Well data & CRDA & Value table & $\begin{array}{c}\text { Aquifer media, } \\
\text { Impact of the vadose } \\
\text { zone, } \\
\text { Depth to water }\end{array}$ \\
$\begin{array}{c}\text { Annual } \\
\text { rainful }\end{array}$ & INM & Value table & Net Recharge \\
$\begin{array}{c}\text { Soil map } \\
\text { Topographic } \\
\text { map }\end{array}$ & CRDA & map & Soil media \\
$\begin{array}{c}\text { OTC } \\
\text { Drilling log }\end{array}$ & DGRE & map & $\begin{array}{c}\text { Topography } \\
\text { Aquifer media, }\end{array}$ \\
$\begin{array}{c}\text { Hydraulic } \\
\text { Conductivity }\end{array}$ & CRDA & Value table & Hydraulic Conductivity \\
\hline \hline
\end{tabular}

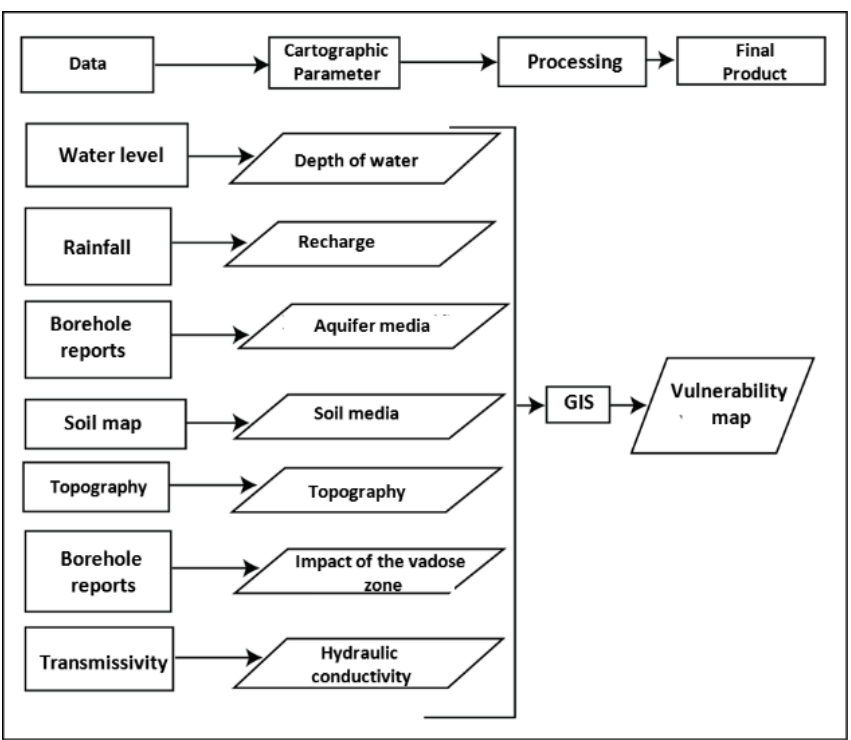

Fig. 3. The flow work chart of the methodology.

\section{Topography}

Topography refers to the ground surface slope. The slope affects the pollution flow and is related to the impact on the water flow and soil expansion in the region. Generally, the slopes between $0 \%$ and $2 \%$ have the greatest potential for contamination transmission and the slopes above $80 \%$ have the lowest potential.

\section{Impact of the vadose zone}

This in understood as unsaturated zone material. It is a zone that is significantly restrictive, found above an aquifer constituting the confining layers. It is used in a confined aquifer, as the type of media with the most substantial impact.

\section{Hydraulic Conductivity}

It is about the extent to which an aquifer can transmit water. It controls the groundwater flow rate, under a given hydraulic gradient.

The DRASTIC index is calculated, which gives us the possibility to identify the area's most sensitive to groundwater contamination compared to other less vulnerable areas. The highest DRASTIC index indicates the potential groundwater for pollution. Fig. 3 shows the methodology flow work chart.

This method was coupled with GIS in raster mode [14] in order to calculate DRASTIC vulnerability index by the sum of the scores of the vulnerability factors multiplied by their respective weights in Table II according to the equation below:

$$
\mathrm{Id}=\mathrm{DrDw}+\mathrm{ArAw}+\mathrm{SrSw}+\mathrm{TrTw}+\mathrm{CrCw}+\mathrm{RrRw}+\mathrm{IrIw}
$$

with

Id is a DRASTIC vulnerability index.

$r$ is the rating of each range of each parameter.

$\mathrm{w}$ is the Weight of each DRASTIC parameter.

\section{RESUlTS AND DISCUSSION}

\section{A. Depth to Water}

The distance of the water table depth ranges from $1.5 \mathrm{~m}$ in the western parts, to $9 \mathrm{~m}$ in the eastern parts of the plain and from 0 to $1.5 \mathrm{~m}$ in the central zone. The depth to water table map in the Aousja-Ghar El Melh plain based on DRASTIC Model rating is shown in Fig. 4. A low water depth will result in a higher vulnerability rating. According to this parameter, the most vulnerable area is the western part.

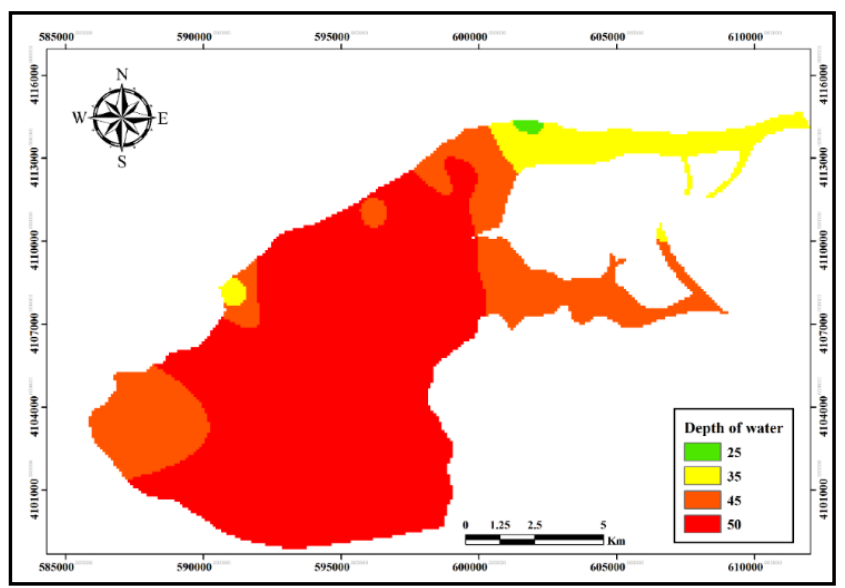

Fig. 4. Depth to water map after DRASTIC Model rating.

\section{B. Net Recharge}

The net recharge map of the plain based on DRASTIC Model rating is shown in Fig. 5. This map was prepared based on three overlapping components: amount of annual rainfall, slope, and soil permeability [15]. Fig. 5 shows that net recharge represents a homogeneous DRASTIC rating across the study area. The net recharge ranges from 380 to 570 . According to the DRASTIC Model, a rating of 9 and a weighting of 4 are assigned to all parts of study area. 


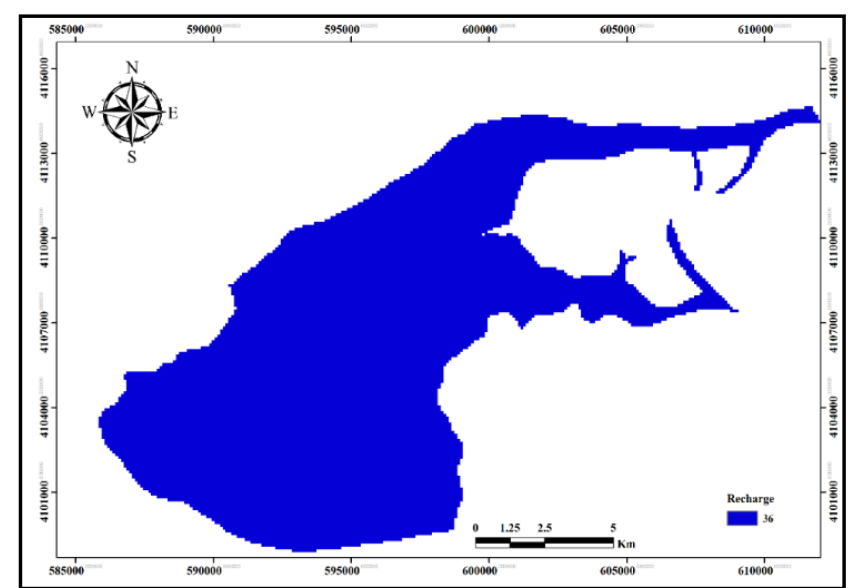

Fig. 5. Net Recharge map after DRASTIC Model rating.

\section{Aquifer Media}

The aquifer media map is generated through the use of information obtained from exploratory drilling and geophysical studies in the study area. The Aousja-Ghar El Melh aquifer is located in the Plio-Quaternary sedimentation levels. The correlation tests carried out showed that these levels are characterized by limited horizontal extent and poor vertical continuity. These different lithological types were treated with the same approach; only the estimated equivalent permeability is a horizontal permeability.

The horizontal equivalent permeability is calculated as follows:

$$
K h=K e q=\frac{h 1 \cdot k 1+h 2 \cdot k 2+\ldots+h n \cdot k n}{H}
$$

with

$\mathrm{Kh}=$ Horizontal permeability $(\mathrm{m} / \mathrm{s})$,

Keq= Estimated equivalent permeability $(\mathrm{m} / \mathrm{s})$.

$\mathrm{H}=$ Total thickness of aquifer $(\mathrm{m})$,

$\mathrm{h}=$ Thickness of each layer of the aquifer $(\mathrm{m})$,

$\mathrm{k} 1 \ldots \mathrm{n}=$ Permeability of each layer of the aquifer (layer 1 to layer $n)(\mathrm{m} / \mathrm{s})$.

In the study area, the permeability of the aquifer is classified in six intervals between $4 \times 10^{-6} \mathrm{~m} / \mathrm{s}$ to $3.5 \times 10^{-3} \mathrm{~m} / \mathrm{s}$ according to increasing vulnerability potentials. It is rated between 1 and 10 and is affected by a weight of 3 (Fig. 6).

\section{Soil Media}

The soil nature of the Aousja-Ghar El Melh region is generally carbonate and isohumic. Overall, these soils have a coarse texture. Depending on the percentage of organic matter present and the possibility of formation of organomineral complexes, the different soil types in the study area are identified. Six classes are defined [15]: Urban area, Halomorphic soil, Gypsum soil, Complex soil, Poorly evolved soil, Calcareous soil. These classes were assigned a rating interval, variable from 1 to 6 , according to the DRASTIC method (Table II) and affected by a weight of 2 (Fig. 7).

\section{E. Topography}

From the slope map, four classes are defined. The lowest slope $(0-2 \%)$ dominates almost the entire study area. These classes were assigned a rating interval, variable from 1 to 10 , according to the DRASTIC method (Table II) and affected by a weight of 1 .

TABLE II: WEIGHTS ASSIGNED TO DRASTIC PARAMETERS

\begin{tabular}{|c|c|c|c|c|}
\hline & Range & Rating & Index & Weight \\
\hline \multirow{4}{*}{$\begin{array}{l}\text { Depth to } \\
\text { water }\end{array}$} & $0-1.5$ & 10 & 50 & \multirow{4}{*}{5} \\
\hline & $1.5-4.5$ & 9 & 45 & \\
\hline & $4.5-9$ & 7 & 35 & \\
\hline & $9-15$ & 5 & 25 & \\
\hline \multirow{5}{*}{$\begin{array}{c}\text { Net } \\
\text { Recharge }\end{array}$} & $380-400$ & 9 & 36 & \multirow{5}{*}{4} \\
\hline & $400-420$ & 9 & 36 & \\
\hline & $420-480$ & 9 & 36 & \\
\hline & $480-500$ & 9 & 36 & \\
\hline & $500-570$ & 9 & 36 & \\
\hline \multirow{6}{*}{$\begin{array}{l}\text { Aquifer } \\
\text { media }\end{array}$} & $410-6-510-5$ & 1 & 3 & \multirow{6}{*}{3} \\
\hline & $510-5-210-4$ & 2 & 6 & \\
\hline & $210-4-410-4$ & 4 & 12 & \\
\hline & $410-4-510-4$ & 6 & 18 & \\
\hline & $510-4-10-3$ & 8 & 24 & \\
\hline & $10-3-3,510-3$ & 10 & 30 & \\
\hline \multirow{6}{*}{ Sol media } & Urban zone & 1 & 2 & \multirow{8}{*}{2} \\
\hline & Halomorphic soils & 2 & 4 & \\
\hline & Gypsum soils & 3 & 6 & \\
\hline & complex of soils & 4 & 8 & \\
\hline & Poorly evolved soils & 5 & 10 & \\
\hline & Calcareous soils & 6 & 12 & \\
\hline \multirow{5}{*}{ Topography } & $>18$ & 1 & 1 & \\
\hline & $12-18 \%$ & 3 & 3 & \\
\hline & $12-18 \%$ & 5 & 5 & \multirow{4}{*}{1} \\
\hline & $2-6 \%$ & 9 & 9 & \\
\hline & $0-2 \%$ & 10 & 10 & \\
\hline \multirow{5}{*}{$\begin{array}{c}\text { Impact of } \\
\text { the vadose } \\
\text { zone }\end{array}$} & $510^{-5}-210^{-4}$ & 2 & 10 & \\
\hline & $210^{-4}-410^{-4}$ & 4 & 20 & \multirow{4}{*}{5} \\
\hline & $410^{-4}-510^{-4}$ & 6 & 30 & \\
\hline & $510^{-4}-10^{-3}$ & 8 & 40 & \\
\hline & $10^{-3}-10^{-2}$ & 10 & 50 & \\
\hline \multirow{3}{*}{$\begin{array}{l}\text { Hydraulic } \\
\text { Conductivity }\end{array}$} & $510^{-5}-210^{-4}$ & 2 & 6 & \multirow[b]{3}{*}{3} \\
\hline & $210^{-4}-410^{-4}$ & 4 & 12 & \\
\hline & $410^{-4}-510^{-5}$ & 6 & 18 & \\
\hline
\end{tabular}

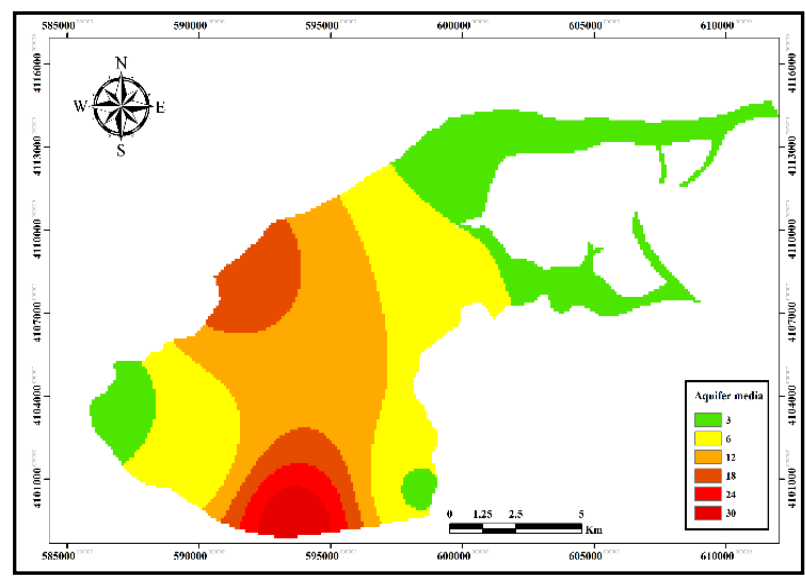

Fig. 6. Aquifer media map after DRASTIC Model rating.

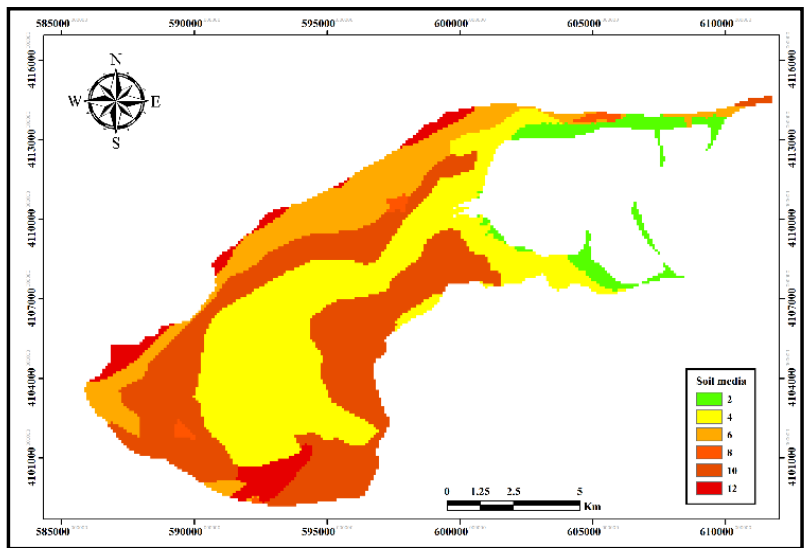

Fig. 7. Soil media map after DRASTIC Model rating. 
The map that generated show the predominance of slopes below $2 \%$ (Fig. 8) hence the possibility of increased pollutants infiltration into the water table.

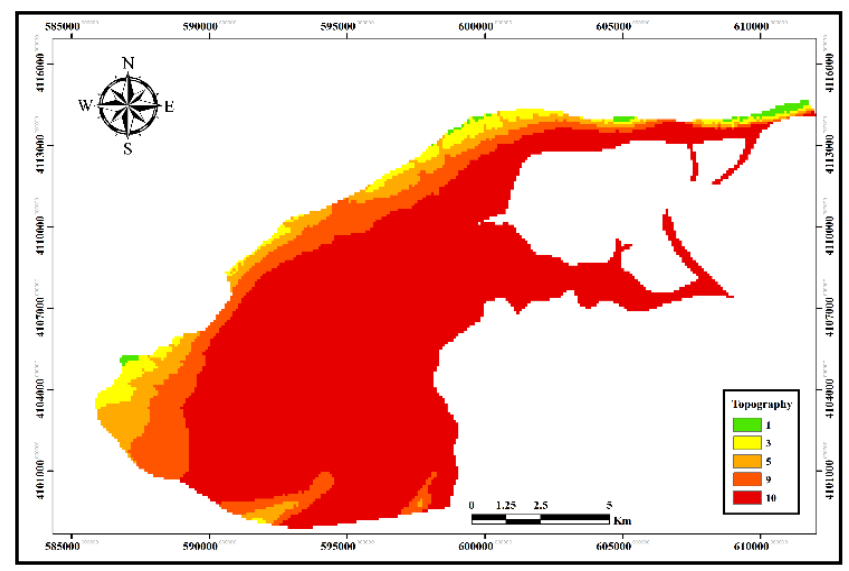

Fig. 8. Topography map after DRASTIC Model rating.

\section{F. Impact of the Vadose Zone}

The lithology of the vadose zone is elaborated from the completion reports of the boreholes and piezometers carried out in the study area.

To elaborate the lithology map of the vadose zone, eleven piezometers are considered. The determination of the lithostratigraphic log for each piezometer was made either from the electric cores or from the existing lithological data generated from the logs of the mechanical boreholes.

From these litho-stratigraphic logs, we tried to correlate the piezometers between them in order to limit the reservoir level and the vadose zone.

To better understand the lithological nature of the vadose zone in the study area, a mean vertical permeability $\left(\mathrm{K}_{\mathrm{mv}}\right)$ or equivalent permeability (Keq) for each lithological formation is calculated.

The equivalent or average permeability in this case is the vertical one, is calculated as follows:

$$
K_{m v}=K e q=\frac{h 1 / k 1+h 2 / k 2+\ldots+h n / k n}{H}
$$

\section{with}

$\mathrm{K}_{\mathrm{mv}}=$ mean vertical permeability $(\mathrm{m} / \mathrm{s})$,

$\mathrm{H}=$ Total thickness of the vadose zone $(\mathrm{m})$,

$\mathrm{h}=$ Thickness of each layer of the vadose zone $(\mathrm{m})$,

$\mathrm{k} 1 \ldots \mathrm{n}=$ Permeability of each layer of the vadose zone (layer 1 to layer $n)(\mathrm{m} / \mathrm{s})$.

The resultant map shows values that vary between $5 \times 10^{-5} \mathrm{~m} / \mathrm{s}$ et $10^{-2}$. These classes were assigned a rating interval, variable from 2 to 10 , according to the DRASTIC method (Table II) and affected by a weight of 5 .

The map in Fig. 9 shows that the lithology of the vadose zone in the western and central parts represents an important DRASTIC note. Which means that these parts are composed of permeable materials, therefore the risk of pollution is high.

\section{G. Hydraulic Conductivity}

To produce the hydraulic Conductivity map, we looked at the data concerning two parameters: the transmissivities as measured in the pumping tests and the thickness of the aquifer, determined from well logs.

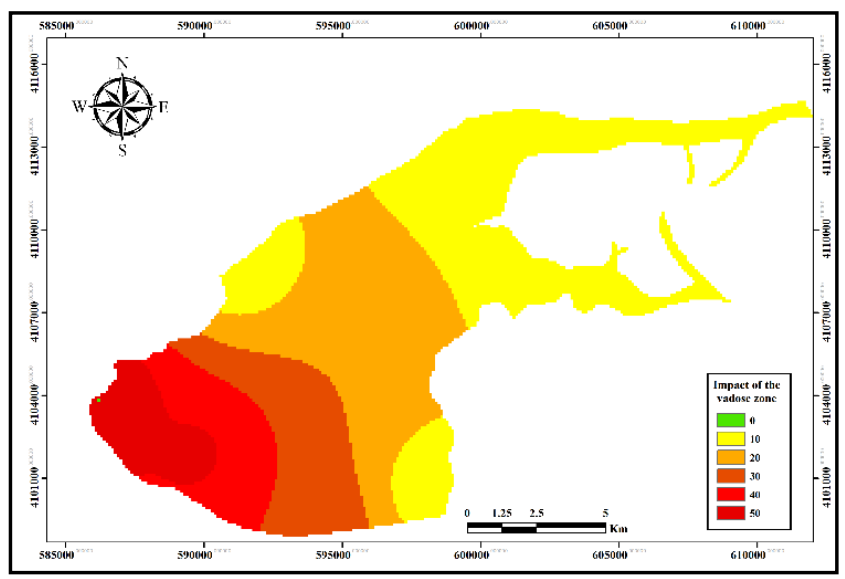

Fig. 9. Impact of the vadose zone map after DRASTIC Model rating.

Pumping tests were performed in five out of the eleven piezometers. The hydraulic conductivity of the Aousja-Ghar el Melh aquifer is calculated based on the following equation:

$$
\mathrm{K}=\mathrm{T} / \mathrm{e}
$$

where:

$\mathrm{k}$ is the hydraulic conductivity of the aquifer $(\mathrm{m} / \mathrm{s})$,

$\mathrm{T}$ is the transmissivity $\left(\mathrm{m}^{2} / \mathrm{s}\right)$,

$\mathrm{e}$ is the thickness of the aquifer (m).

The hydraulic conductivity map in Fig. 10, generated by interpolation, was classified into five classes which were assigned a rating interval, variable from 2 to 10 , according to the DRASTIC method (Table II) and multiplied by the weighting factor 3 .

The study area is found to be highly permeable in the western part, while the low values are shown towards the east

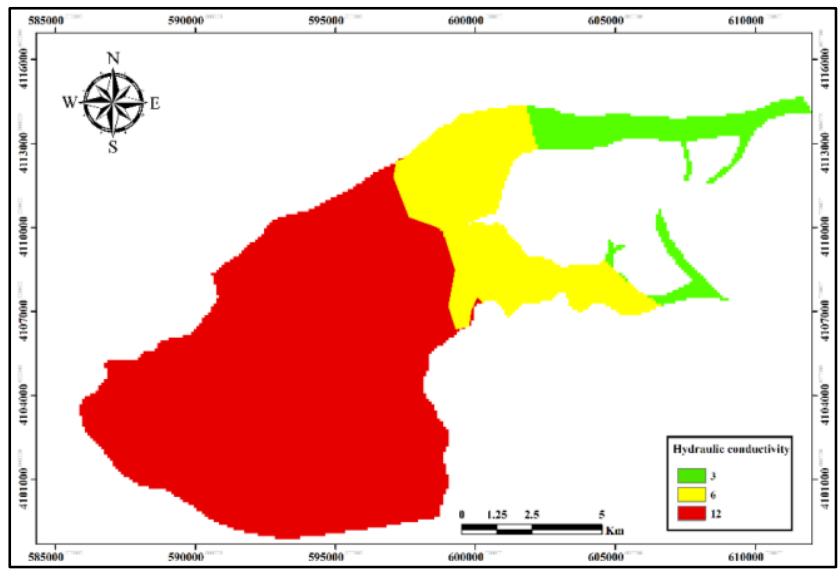

Fig. 10. Hydraulic Conductivity map after DRASTIC Model rating.

\section{H. The DRASTIC Vulnerability Indexes}

As noted above, the DRASTIC Index relatively measures groundwater vulnerability. The vulnerability of the aquifer to contamination is more pronounced as the index gets higher. This index is calculated by summing the contribution of the seven parameters, weighted according to the importance of each one of them (Table II).

The final DRASTIC index vulnerability map of the Aousja-Ghar El Melh aquifer (Fig. 11), shows DRASTIC values ranging from 89 to 175 . 
The vulnerability map of the Aousja-Ghar El Melh aquifer allows to visualize the main risk areas, which are linked to high index. To characterize this vulnerability, this range is classified on the basis of [12] classification.

- 80-120 Low vulnerability;

- 121-160 Moderate vulnerability;

- 161-200 High vulnerability.

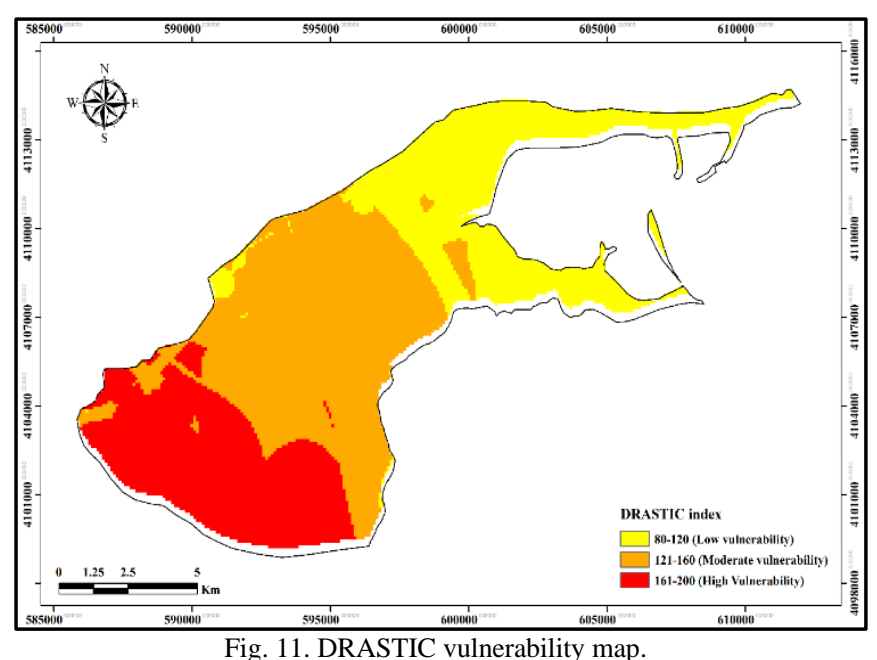

The DRASTIC vulnerability map (Fig. 11) shows that the study area is characterized by different vulnerabilities.

- Low vulnerability sites are located in the northeastern portion of the aquifer, which covers an area of $37.25 \mathrm{~km}^{2}$ representing $28 \%$ of the total study area.

- Moderate vulnerability zone covers the center of the study area with an area of $59.47 \mathrm{~km}^{2}$ representing $45 \%$ of the total study area.

- Finally, High vulnerability sites extending over the western part of the aquifer, with an area of $35.45 \mathrm{~km}^{2}$ representing $27 \%$ of the total study area.

On the basis of the DRASTIC map, it can be concluded that there exist three classes of vulnerability: low, medium, and high (Fig. 11). Groundwater contamination risk is in the western part where human activities are more concentrated. Low vulnerability characterizes the remaining aquifer (eastern part) where anthropogenic activities are absent (Fig. 11).

The application of the DRASTIC method is proved to be of great efficiency to estimate groundwater contamination risk, but it also has some limits. The different sources and scale of data used as input on DRASTIC approach can result in the use of a variety of assessments for the same case study region [17].

For example, attributing the exact value of permeability to each lithology is not as easy as it may seem, due to aquifer heterogeneity and vadose zone media. Also, DRASTIC index can be easily affected by parameter scores. We should highlight the arbitrariness of the weightings and the parameters' numerical values.

In the vulnerability index development, the presumably faster groundwater recharge, which is associated with artificial recharge, faults and wadis was not taken into account, even though these are considered crucial local recharge areas. This remains a downside in the application of the DRASTIC methodology [17]. Another main weakness is to do with the challenge to validate vulnerability mapping [18].

In our case, validating groundwater vulnerability assessment can be done using nitrate concentration. In Aousja-Ghar El Melh acquifer, nitrate measurements from analysis of groundwater samples, after interpolation, Fig. 12 show a high concentration in western part of aquifer, which decreases in the eastern part.

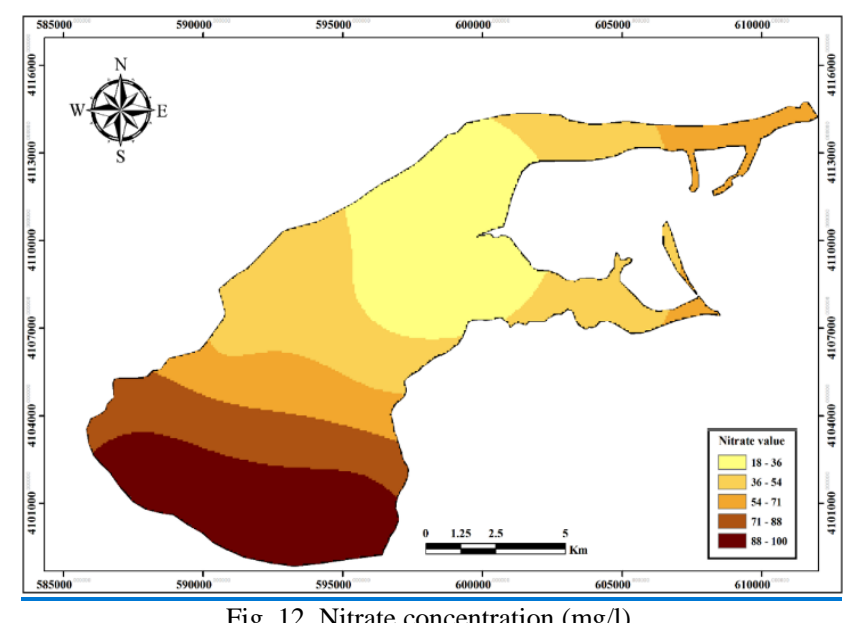

V. CONCLUSION

The generated vulnerability map of Aousja-Ghar El Melh aquifer shows three degrees: low, moderate and high vulnerability. This map seems to be promising in quantifying agricultural practice impact on groundwater quality. Such a map could generally guide our work on vulnerability and risk. However, local managers and planners must take into account local water resources conditions. There is a need for an integration of indicators that encompass the environment (vulnerability), economy (groundwater extraction and agricultural purposes) and society (groundwater accessibility and use). This is imperative to understand and assess the crucial state of groundwater resources. As such, efficacious hydrogeologic models and vulnerability investigations meant to help preserve water resources are to be appreciated by managers and planners.

\section{ACKNOWLEDGEMENT}

I wish to acknowledge the CRDA (Regional Agency of Agricultural Development of Bizerte) for the sincerity of cooperation and the provision of data.

\section{REFERENCES}

[1] D.K. Todd, Groundwater Hydrology, 2 nd ed. New York: Wiley, 1980, 535pp.

[2] J. C. Prior, J. L. Boekhoff, M. R. Howes, R. D. Libra, and P. E. VanDorpe, "Iowa's groundwater basics: A geological guide to the occurrence, use, and vulnerability of Iowa's aquifers," In Iowa Geological Survey Educational Series: Vol. 6, 2003.

[3] J. Vrba and A. Zaporozec, Guidebook on Mapping Groundwater Vulnerability, IAH International Contributions to Hydrogeology, 16. FRG, Heise Publication, Hannover, 1994, 131 p.

[4] J. Margat, Groundwater vulnerability to contamination, In: J. Vrba, and A. Zoporozec, (eds.) 1994. Guidebook on mapping groundwater vulnerability, International Association of Hydrogeologists. 
International contributions to Hydrogeology Volume 16, Verlag Heinz Heise, Hannover, germany, 1968, 131p.

[5] R.J. Kalinski, W.E. Kelly, I. Bogardi, R.L. Ehrman and P.D. Yamamoto, "Correlation between DRASTIC vulnerabilities and incidents of VOC contamination of municipal wells in Nebraska," Groundwater, vol. 1, pp. 31-34, 1994.

[6] P.F. Burollet, Étude géologique des bassins mio-pliocènes du Nord-Est de la Tunisie, Annales des Mines et de Géologie, Tunis 7, 1951.

[7] P. Besème, and T. Lajmi, "Le Pliocène marin du lac Ichkeul (coupe du Jebel Merzaguine): Son contexte géologique, son évolution sédimentologique, son contenu microfaunistique," Actes du Premier Cong. Nat. Sc. Terre, Tunis, pp. 69-83, 1981.

[8] M. Bel Haj Ali, L. Chihi, M. Rabhi, "Le Néogène de Tunisie: Analyse des séries stratigraphiques et le rôle de la tectonique et de l'halocinèse dans la genèse des bassins," Proceedings of the 6th Tunisian Petroleum Exploration and Production Conference, vol.12, pp. 59-76, 1998.

[9] C. Arambourg and M. Arnould, "Notes sur les fouilles paléontologiques exécutées en 1947-1948 et en 1949 dans le gisement villafranchien de la Garaet Ichkeul," Bulletin De La Societe des Sciences Nature, vol. 3, pp. 149-157, 1949.

[10] R. Paskoff and P. Sanlaville, "Les côtes de la Tunisie. Variation du niveau marin depuis le Tyrrhénien," Collect. Maison Orient. Méditerr., Service Géographie Préhist., vol. 2, France, 1983.

[11] R.M. Mohamed, "Evaluation et cartographie de la vulnérabilité à la pollution de l'aquifère alluvionnaire de la plaine d'El Madher, NordEst algérien, selon la méthode DRASTIC," Sciences et changement planétaires/sécheresse, vol. 12, pp. 95-101, 2001.

[12] L. Aller, T. Bennet, J.H. Lehr et R. Petty, DRASTIC: Standardized System for Evaluating Ground Water Pollution Potential Using Hydrogeologic Settings, Office of Research and Development, Environmental Protection Agency, 1987, 622 pp.

[13] F. Melki, T. Zouaghi, S. Harrab, A. Casas Sainz, M. Bédir, F. Zargouni, "Structuring and evolution of Neogene transcurrent basins in the Tellian foreland domain, northeastern Tunisia," J. Geodyn., 52 (2011), pp. 57-69.

[14] M. Sinan and M. Razack "An extension to the DRASTIC model to assess groundwater vulnerability to pollution: application to the Haouz aquifer of Marrakech (Morocco)," Environ. Geol. vol. 52, pp. 349-363, 2009.

[15] G. Piscopo, "Groundwater vulnerability map, explanatory notes," Australia: Castlereagh Catchment, NSW Department of Land and Water Conservation, 2001

[16] CRDA (Regional Agency of Agricultural Development of Bizerte), Comptes rendus des forages et piézomètres de surveillance du gouvernorat de Bizerte, 2010.

[17] S. Saidi, S. Bouri and H. Ben Dhia, "Groundwater vulnerability and risk mapping of the Hajeb-jelma aquifer (Central Tunisia) using a GISbased DRASTIC model," Environ. Earth Sci. vol. 59, pp. 1579-1588, 2010.

[18] B. Andreo, N. Goldscheider, I. Vadillo, J. Maria Vias, C. Neukum, M. Sinreich, P. Jime'nez, J. Brechenmacher, F. Carrasco, H. Hotzl, M. Jesus Perles and F. Zwahlen, "Karst groundwater protection: first application of a Pan-European Approach to vulnerability, hazard and risk mapping in the Sierra de Libar (Southern Spain)," J Sci Total Env. Vol. 357, pp. 54-73, 2005.

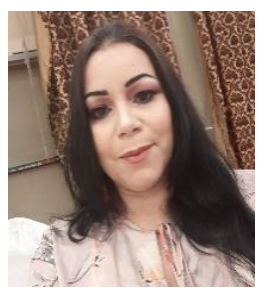

Dr. Sarra Alhabib Ouerghi is from El KefTunisia and was born on 16th August 1978. She received her $\mathrm{PhD}$ in Engineering of environment and planning from National Engineering School of Sfax (ENIS), Tunisia, in 2014, M.Sc. in Geomatic from National Engineering School of Tunis (ENIT), Tunisia, in 2006, M.Sc. in sedimentary basins's Geology and Georesources from Faculty of Sciences of Tunis (FST), Tunisia, in 2004 and her License in Earth Sciences, Georessources section from Faculty of Sciences of Tunis (FST), Tunisia, in 2002. Currently, Dr. Sarra Alhabib Ouerghi is an Assistant Professor in Department of Geographic, Faculty of Arts \& Humanities King Abdulaziz University, Saudi Arabia. She has various publications in referred journals and conference proceedings. 